\title{
PERANAN SISTEM ERP DAN PERUBAHAN POLA KERJA SEBAGAI UPAYA MENINGKATKAN KINERJA PERUSAHAAN
}

\author{
Hendra Alianto; Santo F Wijaya \\ Information Systems Department, School of Information Systems, Binus University \\ Jl. K.H. Syahdan No. 9, Palmerah, Jakarta Barat 11480 \\ hendraalianto@yahoo.com; santofwijaya@yahoo.com
}

\begin{abstract}
The ERP system is an integrated system that supports the core business activities of a company. These activities include manufacturing, logistics, finance and accounting, sales and marketing, and human resources. The ERP system will help related departments in a company to share data and information, cost reduction, and improved management of business processes, which will have an impact on work activities become more efficient and more effective. The method in this research is a case study approach, analysis, evaluation of documents and data collection. This study aims to discuss how the role of the ERP system and changes in work patterns as an effort to improve the performance of companies backed by the role of the ERP system.
\end{abstract}

Keywords: ERP system, improved, changes

\begin{abstract}
ABSTRAK
Sistem ERP merupakan suatu sistem terintegrasi yang mendukung aktivitas-aktivitas bisnis inti dari sebuah perusahaan. Aktivitas-aktivitas ini meliputi bagian manufaktur, logistik, keuangan dan akuntansi, penjualan dan pemasaran, dan sumber daya manusia. Sistem ERP akan membantu departemen-departemen terkait di sebuah perusahaan untuk berbagi data dan informasi, pengurangan biaya, dan perbaikan manajemen dari bisnis proses, yang akan berdampak pada aktivitas pekerjaan menjadi lebih efisien dan lebih efektif. Metode dalam penelitian ini adalah pendekatan studi kasus, analisa, evaluasi terhadap dokumen-dokumen dan pengumpulan data. Penelitian ini bertujuan untuk membahas bagaimana peranan sistem ERP dan perubahan pola kerja sebagai upaya meningkatkan kinerja perusahaan yang didukung oleh peran sistem ERP.
\end{abstract}

Kata kunci: sistem ERP, perbaikan, perubahan 


\section{PENDAHULUAN}

Sistem Informasi merupakan aset bagi suatu perusahaan di mana bila diterapkan secara baik, maka sistem informasi tersebut akan memberikan kelebihan untuk berkompetisi dan meningkatkan kesuksesan bagi perusahaan. Salah satu sistem informasi yang terintegerasi adalah dengan penerapan sistem ERP. Sistem ERP merupakan paket aplikasi program terintegrasi, multi modul yang dirancang untuk melayani dan mendukung berbagai fungsi dalam perusahaan (to serve and support multiple business functions), sehingga aktivitas pekerjaan menjadi lebih efisien dan dapat memberikan pelayanan lebih bagi konsumen, yang akhirnya dapat memberikan keuntungan maksimal bagi perusahaan. Untuk mencapai hal tersebut, agar sistem ERP dapat meningkatkan kinerja suatu perusahaan dan mengubah pola pikir maupun pola kerja, maka perlu diperhatikan langkah-langkah dari tingkat pengguna sampai tingkat manajerial agar sistem ERP yang dibangun dapat berhasil baik.

ERP oleh pakar didefinisikan sebagai (O’Leary, 2009), “Enterprise Resource System (ERP) sistems are computer based systems designed to process an organization's transactions and facilitate integrated and real-time planning, production, and customer response. In particular ERP systemswill be assumed to have certain characteristics". Sedangkan menurut Monk et al (2009), "Enterprise Resource System (ERP) programs are core software used by companies to coordinate information in every area of the business. ERP programs help to manage company wide business processes, using a common database and shared management reporting tools".

Dari definisi sistem ERP tersebut di atas, konsep system ERP dikembangkan dengan latar belakang pemikiran kepentingan aktivitas pengintegrasian proses secara lintas fungsi di dalam perusahaan dilakukan, agar dapat lebih responsif terhadap berbagai kebutuhan pelanggan. Aplikasi program atau software dalam konsep ERP adalah agar perangkat teknologi informasi tersebut dapat memberikan nilai tambah, seperti penghapusan proses-proses yang tidak perlu (process elimination), penyederhanaan proses-proses yang rumit (process simplification), penyatuan proses-proses yang redundansi (process integration), dan pengotomatisasian proses-proses yang manual (process automation).

Selanjutnya O’Leary (2009), menyatakan bahwa karakteristik system ERP meliputi hal-hal sebagai berikut ini: Sistem ERP adalah suatu paket perangkat lunak yang didesain untuk lingkungan pelanggan pengguna server, apakah itu secara tradisional atau berbasis jaringan, memadukan sebagian besar dari proses bisnis, memproses sebagian besar dari transaksi perusahaan, menggunakan database perusahaan yang secara tipikal menyimpan setiap data sekali saja, memungkinkan mengakses data secara waktu nyata (real time), memungkinkan perpaduan proses transaksi dan kegiatan perencanaan, menunjang sistem multi mata uang dan bahasa, yang sangat diperlukan oleh perusahaan multinasional dan memungkinkan penyesuaian untuk kebutuhan khusus perusahaan tanpa melakukan pemrograman kembali.

Dalam melakukan penerapan sistem ERP banyak dijumpai permasalahan teknis dan non teknis terlebih jika menghadapi pengguna level manajerial, di mana pengguna tidak bersedia menggunakan sistem baru yang telah tersedia, dengan memberikan beberapa alasan, yang intinya sistem baru tersebut dinilai tidak sesuai dengan kebutuhan.

Secara umum, permasalahan yang dihadapi adalah sebagai berikut: (1) Agar berperan dalam meningkatkan kinerja perusahaan, penerapan Sistem ERP merupakan proyek yang menuntut kerja keras dan kerja cerdas. (2) Penerapan Sistem ERP yang terintegrasi tidak dapat dilakukan dengan sendiri. (3) Perubahan pola kerja yang membutuhkan proses dan usaha yang maksimal. 
Peranan sistem ERP ditujukan untuk meningkatkan kinerja perusahaan, mengurangi peluang terjadinya kesalahan yang disebabkan oleh manusia akibat penggunaan sistem manual, membantu perusahaan untuk meningkatkan efisiensi dan efektifitas kerja. Secara umum penelitian ini bertujuan untuk untuk membahas bagaimana peranan sistem ERP dan perubahan pola kerja sebagai upaya meningkatkan kinerja perusahaan. Dari hasil penelitian ini diharapkan akan mendapatkan manfaat bagi perusahaan, dapat memberikan solusi terhadap permasalahan-permasalahan umum yang biasanya dihadapi perusahaan dalam mengubah pola kerja untuk meningkatkan kinerja perusahaan didukung dengan peranan sistem ERP.

\section{METODE PENELITIAN}

Metodologi yang digunakan dalam penelitian ini adalah dengan pendekatan studi kasus, analisis, dan evaluasi serta studi literatur terhadap dokumen-dokumen organisasi yang berkenaan dengan strategi organisasi, rencana manajerial dan operasional, serta penggunaan teknologi dan sistem informasi yang ada pada organisasi. Disamping itu juga menggunakan metode studi pustaka, yaitu menggunakan beberapa buku dan literatur yang berkaitan dengan objek penelitian ini, terutama hal berkaitan sistem ERP yang digunakan sebagai referensi, juga menggunakan metode lapangan, yaitu penulis melakukan pengamatan langsung dan pengalaman penulis sebagai praktisi dan konsultan di bidang sistem informasi, dengan melakukan analisis terhadap penemuan fakta dan memberikan beberapa alternatif pemecahan permasalahan yang dihadapi.

Untuk mendapatkan data yang akan diolah, maka dalam penelitian ini dilakukan tiga teknik pengumpulan data, yaitu: (a) Studi literature; studi literatur dilakukan dengan membaca artikel atau tulisan-tulisan yang terkait dengan topik penelitian melalui buku, jurnal, dan internet. (b) Wawancara; wawancara akan dilakukan dengan manajemen dan orang-orang yang terkait dengan topik penelitian. (c) Observasi; pada metode obsevasi ini tim melakukan pengamatan langsung pada bagian-bagian terkait dengan penelitian. Penelitian ini dibutuhkan untuk mengetahui proses bisnis yang sedang berjalan, melihat informasi apa saja yang didapatkan dan dibutuhkan, dan teknologi yang dipakai oleh organisasi serta melihat kinerja dari mereka yang terkait dengan proses bisnis. (d) Kuesioner; kuesioner merupakan teknik pengumpulan data yang dilakukan dengan cara memberi seperangkat pertanyaan tertulis yang akan dibagikan kepada mereka yang terlibat pada proses bisnis.

Tujuan penulisan penelitian ini bertujuan untuk membahas bagaimana peranan sistem ERP dan perubahan pola kerja untuk meningkatkan kinerja perusahaan dan diharapkandapat memiliki pengaruh signifikan dalam upaya untuk meningkatkan proses bisnis internal perusahaan yang menghasilkan peningkatan yang signifikan dalam kualitas dan efisiensi operasional didukung dengan perubahan pola kerja.

\section{HASIL DAN PEMBAHASAN}

\section{Peranan Sistem ERP}

Melalui sistem ERP dapat mendukung sinergi dari semua fungsi-fungsi yang ada dalam perusahaan. Sistem ERP dapat melibatkan seluruh fungsi manajemen baik akuntansi dan keuangan, produksi (manufaktur), penjualan dan marketing, pembelian, gudang, dan sumber daya manusia. Dengan penerapan Sistem ERP, maka otomatis dapat meningkatkan kinerja usaha (good performance) perusahaan. Dengan demikian melalui sistem informasi enterprise yang terintegrasi, maka dapat dikatakan bahwa sistem ERP dapat mendukung sinergi dari semua bagian yang ada dalam suatu perusahaan. Contohnya: ketika seorang pelanggan melakukan input data pesanan dalam suatu aplikasi 
program ERP, maka secara otomatis pelanggan akan memperoleh semua informasi lengkap yang berkaitan dengan pesanan tersebut, seperti nilai hutang/tagihan, riwayat pesanan sebelumnya, tingkat persediaan pesanannya di gudang, jadwal pengiriman pesanannya, dan informasi lainnya yang dibutuhkan.

Dengan rantai nilai (value chain), di mana aktivitas perusahaan dimulai dengan adanya suatu permintaan pelanggan dan pasar terhadap suatu produk tertentu. Dengan sumber daya yang ada, maka perusahaan akan berusaha untuk memproses bahan baku menjadi produk yang diinginkan pelanggan. Rangkaian proses atau aktivitas perubahan bahan menjadi produk tersebut, dikenal dengan istilah rantai nilai (value chain). Dengan melakukan integrasi rantai nilai perusahaan dengan berbagai rantai nilai mitra bisnisnya, maka akan diperoleh berbagai manfaat yaitu Perusahaan tidak perlu menimbun bahan di gudang dengan nilai yang signifikan, karena sudah mengetahui jumlah stock dan durasi pengiriman (leadtime) dari para pemasoknya, menciptakan produk secara lebih murah, cepat, dan berkualitas, karena telah terjalinnya jaringan proses antara pemasok dan perusahaan dan meningkatkan keuntungan (profitable) secara signifikan, karena kemampuan untuk menyatukan rantai nilai dari departemen yang terlibat dalam sistem penciptaan produk, sehingga perusahaan dapat berkonsentrasi pada kompetensi utamanya, dan melakukan outsourcing untuk proses pendukung lainnya.

Secara umum, sistem ERP meningkatkan proses bisnis internal perusahaan sehingga menghasilkan peningkatan signifikan dalam kualitas dan efisiensi layanan pelanggan, produksi dan distribusi. Sistem ERP juga mampu menurunkan biaya pemrosesan transaksi secara signifikan, mempermudah tugas dan fungsi manajemen sehari-hari dalam mengambil keputusan, meningkatkan kemampuan pengambilan keputusan secara tepat lintas bisnis perusahaan serta menghilangkan perbedaan budaya antar departemen sehingga data terintegrasi dengan baik. Penerapan system ERP akan menghasilkan struktur organisasi, tanggung jawab manajerial dan peran kerja yang lebih fleksibel. Kemampuan ERP dalam menghasilkan struktur organisasi dan tenaga kerja yang lebih lincah dan adaptif, membuat perusahaan lebih mudah dalam memanfaatkan berbagai peluang baru bisnis dan menghasilkan analisa dan laporan mendukung perencanaan jangka panjang yang dapat dijadikan alat pengambilan keputusan atau sebagai decision support sistem.

Sistem ERP membuat perencanaan aktivitas antar departemen dengan mengelola dan mengalokasikan sumber daya secara efisien dan efektif, misalnya perencanaan pembelian barang, perencanaan produksi, perencanaan cash flow, perencanaan penjualan dan perencanaan biaya. Sistem ERP juga menciptakan struktur organisasi yang ramping dan pembagian kerja yang tepat dengan menggunakan sistem yang terintegrasi untuk seluruh fungsi, baik fungsi penjualan, pembelian, produksi dan keuangan, sehingga dapat menghilangkan pekerjaan-pekerjaan rangkap dan menggunakan standarisasi data untuk seluruh departemen dan menjamin seluruh aktivitas dilakukan sesuai dengan prosedur yang telah ditetapkan, misalnya fungsi pembelian harus melalui perhitungan perencanaan kebutuhan barang, lalu melakukan order pembelian, yang dilanjutkan dengan penerimaan barang, dan selanjutnya membuat pengakuan hutang sehingga seluruh aktivitas dapat berjalan effisien dan efektif. Sistem ERP mengubah pola kerja dan pola pikir seseorang dalam menjalankan aktivitas proses bisnis dan operasional perusahaan.

Yang perlu diperhatikan adalah aktivitas proses "perampingan” ini, yang menyebabkan tenaga kerja tergantikan oleh sistem, tidak selalu akan berdampak pada pemutusan hubungan kerja (PHK). Penerapan sistem ERP ini sering menimbulkan perlawanan yang tinggi karena isu tenaga kerja yang akan digantikan oleh sistem. Pendapat ini keliru, karena salah satu alasan untuk menerapkan konsep sistem ERP adalah untuk melakukan empowerement terhadap manajemen dan pengguna sumber daya manusia. Sebenarnya, dengan penerapan sistem ERP, maka suatu perusahaan tidak perlu lagi membuang banyak waktu untuk melakukan proses-proses yang bersifat administratif (non value added activities). Sumber daya manusia dapat lebih banyak meluangkan waktun untuk memikirkan hal-hal yang bersifat strategis, seperti bagaimana mengembangkan perusahaan, mencari sumber-sumber 
pendapatan baru, mencari lebih banyak pelanggan, menjalin hubungan lebih baik dengan mitra bisnis dan lain sebagainya.

Walaupun demikian, dengan adanya sistem ERP, bukan berarti tidak ada kasus pemutusan hubungan kerja (PHK). Karena banyak sekali kasus penerapan sistem ERP yang bersamaan dengan penerapan konsep manajemen perubahan (change management), semacam Business Process Reengineering (perubahan secara radikal untuk meningkatkan perbaikan kinerja usaha secara dramatis), yang salah satu konsekuensi logisnya adalah perampingan jumlah pengguna sumber daya manusia sesuai kebutuhan.

\section{Permasalahan dalam Implementasi Sistem ERP}

Dalam praktek bisnisnya, sering terjadi hambatan-hambatan dalam melakukan implementasi suatu sistem ERP. Hal-hal inilah yang sering tidak dimengerti oleh banyak perusahaan dan selanjutnya terjebak pada saat mengimplementasikan sistem ERP. Secara umum, hambatan-hambatan atau permasalahan yang dihadapi dalam melakukan Implementasi sistem ERP adalah manajemen teknis, politik dan budaya.

Dalam hal manajemen teknis, masalah bahasa suatu aplikasi ERP dan perubahan cara kerja dari model hardcopy menjadi model display, adalah menjadi kendali teknis yang perlu diperhatikan. Penggunaan aplikasi program ERP menuntut terminologi istilah yang sama, sehingga istilah-istilah dalam modul produksi, penjualan, logistik, keuangan/accounting, sumber daya manusia, dan modul lainnya yang digunakan, haruslah mengalami perubahan yang signifikan sesuai istilah dalam sistem ERP. Misalnya proses persetujuan (approval) dengan sistem ERP, maka pengguna dipaksa melalui proses otorisasi dengan menggunakan komputer melalui model display screen (layar komputer).

Dalam hal politik, kendala yang menghambat implementasi sistem ERP dapat bersumber dari dalam departemen IT sendiri dan dari luar departemen IT. Di mana jika sebagian besar personil IT merasa bahwa pekerjaan mereka, yang semula bertanggung jawab dalam pembuatan aplikasi program sesuai kebutuhan pengguna, akan hilang digantikan oleh sistem ERP. Demikian juga personil di luar departemen IT, akan merasa terancam dengan berkurangnya kekuasaan karena sebagian pekerjaan akan dilakukan oleh sistem ERP. Disamping itu, keenganan pengguna untuk terlibat secara aktif dalam melakukan implementasi sistem ERP disebabkan karena ketidakpercayaan terhadap aplikasi program ERP yang diimplementasikan dapat berjalan baik, malah berspekulasi bahwa implementasi sistem ERP akan menjadi beban dan malah merasa takut bahwa data-data atau laporan-laporan rahasia akan diketahui oleh departemen IT.

Dalam hal budaya, implementasi sistem ERP yang berbasis penggunaan teknologi informasi, akan menuntut perubahan-perubahan yang harus dilakukan pengguna dalam menggunakan aplikasi program ERP. Untuk itu, perlu dilakukan perubahan budaya perusahaan yang menjadikan pekerjaan menjadi lebih efisien dan efektif, dengan adanya implementasi sistem ERP.

\section{Kesuksesan Penerapan Sistem ERP}

Dari kendala-kendala penerapan Sistem ERP yang telah dijelaskan sebelumnya, tidak berarti implementasi sistem ERP tidak bisa dilakukan dengan berhasil. Menurut Turban (2005), faktor-faktor kunci kesuksesan implementasi ERP adalah bisnis proses, manajemen perubahan, migrasi data dan komunikasi dan komitmen.

Dalam hal bisnis proses, penerapkan sistem ERP, perusahaan harus memilih antara mengubah bisnis proses yang dimilikinya untuk menyesuaikan dengan sistem ERP atau sebaliknya. Agar dapat memilih, perusahaan yang akan mengimplementasikan system ERP tentunya harus sudah mempunyai bisnis proses, sehingga dapat membandingkan dengan bisnis proses dari sistem ERP. Dari 
perbandingan tersebut, jika bisnis proses yang dimiliki perusahaan sudah matang, maka tidak perlu mengalami perubahan (modifikasi) aplikasi program.

Manajemen perubahan diperlukan untuk memberikan pendidikan kepada pengguna yang akan bersentuhan langsung dengan sistem yang baru. Secara praktek, untuk mengelola perubahan tersebut, perusahaan dapat mengadopsi beberapa metode yang ada, diantaranya Change Acceleration Project (CAP), yaitu melakukan pendekatan-pendekatan (personal approach) kepada tiap pengguna di departemen terkait untuk mendapatkan komitmen. Komitmen ini sangat penting untuk menyakinkan bahwa departemen terkait akan menggunakan dan mendukung sistem ERP yang akan diimplementasikan. Selain itu pendekatan kepada departemen dilakukan untuk mengatasi kendala politis yang diakibatkan ketakutan akan kehilangan pekerjaan, keraguan akan manfaat dari implementasi sistem ERP.

Setelah testing sistem dilakukan dan sistem ERP siap untuk digunakan oleh departemen terkait, maka tahapan berikutnya adalah migrasi data. Beberapa hal yang perlu diperhatikan: (1) Menentukan pihak-pihak internal yang bertanggung jawab terhadap persiapan data yang diperlukan. Dengan menentukan seseorang sebagai penanggung jawab terhadap persiapan data, maka pengumpulan dan persiapan data untuk proses migrasi dapat dilakukan dengan lebih terencana. (2) Mempersiapkan data dengan detail dan rapih. Pihak pengembang sistem akan melakukan pembuatan program khusus yang hanya digunakan untuk keperluan migrasi data. Hal ini untuk memberikan arahan mengenai jenis data yang dibutuhkan, format data, dan susunan data sesuai dengan program yang sebelumnya telah dibuat. Sangat penting bagi pihak internal untuk mempersiapkan dan menyediakan data sesuai dengan format dan susunan yang telah diarahkan oleh pihak pengembang. Sehingga proses migrasi data dapat dilakukan dengan lebih lancar. (3) Melakukan pemeriksaan data dengan seksama untuk menghindari duplikasi data yang nanti akan dipindahkan ke sistem baru. Pada tahapan migrasi data, perlu diperhatikan bahwa hanya data yang akan digunakan (aktif) yang akan diikutsertakan dalam proses migrasi. Untuk data yang sudah tidak digunakan, tidak perlu diikutsertakan.Sehingga pada tahap ini perlu dilakukan pemeriksaan data yang benar-benar akan digunakan dan juga pemeriksaan data dari kesalahan input atau duplikasi. (4) Melakukan migrasi data untuk keseluruhan data yang diperlukan, bukan hanya untuk data tertentu atau data parsial. Sistem ERP merupakan sistem yang memiliki integrasi antar proses transaksi yang akan dijalankan perusahaan. Hal inilah yang menyebabkan migrasi data diperlukan untuk data transaksi semua departemen dalam perusahaan yang akan menggunakan sistem baru tersebut. Jika ada data terkait yang akan digunakan dalam sistem tetapi tidak diikutsertakan dalam proses migrasi, besar kemungkinan sistem tersebut tidak dapat digunakan untuk mengisi data transaksi. (5) Jangan mempersiapkan data migrasi yang tidak sesuai dengan arahan, format dan susunan yang sebelumnya telah diberikan oleh konsultan. Dengan mempersiapkan dan memberikan data yang tidak sesuai dengan arahan konsultan, maka konsultan akan mengajukan perbaikan data kepada tim internal perusahaan. Pada saat hal ini terjadi, proses persiapan data akan memakan waktu lebih lama karena perbaikan dan perubahan data tersebut. (6) Mempersiapkan data dengan detail dan rapih. Pihak pengembang sistem akan melakukan pembuatan program khusus yang hanya digunakan untuk keperluan migrasi data. Hal ini untuk memberikan arahan mengenai jenis data yang dibutuhkan, format data, dan susunan data sesuai dengan program yang sebelumnya telah dibuat.Sangat penting bagi pihak internal untuk mempersiapkan dan menyediakan data sesuai dengan format dan susunan yang telah diarahkan oleh pihak pengembang. Sehingga proses migrasi data dapat dilakukan dengan lebih lancar.

Komunikasi dan komitmen merupakan hal penting yang perlu selalu dijaga pada saat perusahaan memutuskan untuk melakukan implementasi sistem ERP. Beberapa hal yang perlu diperhatikan: (1) Komunikasi antar anggota tim proyek. Tanpa komunikasi yang baik, maka informasi tidak akan dapat disampaikan dan disebarluaskan ke pihak lain yang berkepentingan. Komunikasi harus selalu terjaga baik di dalam internal tim konsultan, internal tim perusahaan, maupun antar tim konsultan dengan internal perusahaan. Salah satu kunci sukses implementasi sistem ERP adalah komunikasi dan keakraban antar anggota tim proyek baik dari pihak internal maupun dari pihak 
konsultan. Dengan komunikasi yang lancar, maka masing-masing anggota tim akan lebih menyadari tugas dan fungsinya masing-masing, hal ini yang pada akhirnya akan menciptakan sinergi antara anggota tim dan team work yang solid. (2) Komitmen terhadap batas waktu pengerjaan tugas dalam proyek. Pimpinan proyek (Project Manager) akan menentukan waktu pengerjaan proyek dan mensosialisasikan jadwal tersebut kepada seluruh anggota tim proyek. Setiap anggota tim proyek wajib menyelesaikan tugasnya masing-masing sesuai dengan jadwal yang telah ditentukan tersebut. Jika ada bagian tim yang tidak melaksanakan pekerjaannya sesuai dengan jadwal, maka proyek akan mengalami perpanjangan waktu yang dapat menyebabkan kerugian kepada kedua belah pihak (perusahaan dan konsultan). (3) Melibatkan secara aktif sumber daya yang kompeten pada bidangnya. Sumber daya yang tidak kompeten dapat menghambat laju implementasi. Untuk itu kedua belah pihak perlu memastikan bahwa sumber daya yang diikutsertakan dalam proyek adalah orang-orang yang kompeten untuk melakukan tugasnya masing-masing. (4) Jangan melibatkan tenaga kerja kontrak atau non permanen untuk posisi kunci dalam proyek implementasi sistem ERP. Tenaga kerja kontrak atau non permanen mempunyai tenggang masa bekerja pada perusahaan. Perusahaan memiliki resiko kegagalan, jika masa kontrak pengguna yang bersangkutan telah selesai (tidak diperpanjang) dimana pada saat proyek implementasi masih berjalan. (5) Jangan memilih pimpinan proyek yang tidak memiliki pengaruh terhadap tim implementasi. Salah satu unsur penting yang dapat menyukseskan proyek implementasi sistem ERP adalah kharisma dan dedikasi pimpinan proyek terhadap proyek tersebut.Pimpinan proyek mempunyai peran yang penting dalam memotivasi anggota tim, membentuk tim yang solid, dan mengarahkan tim untuk selalu bekerja sesuai dengan target dan jadwal.

\section{Perubahan Pola Kerja}

Setiap perusahaan memiliki gaya atau budaya pola kerja yang sudah berjalan. Budaya atau kebiasaan cara kerja dalam suatu perusahaan merupakan salah satu faktor penting yang harus dipertimbangkan dalam mencapai keberhasilan dalam mengimplementasikan proses perubahan, karena penerapan suatu sistem ERP menuntut budaya pola kerja dengan keterlibatan aktif pengguna. Budaya perusahaan menjadikan perusahaan mempunyai ciri khas yang unik, selaras dengan kebiasaan yang dilakukan sehari-hari. Untuk itu, sumber daya tersebut harus mengerti cara kerja dalam budaya perusahaan tersebut dan mengubah cara kerja sesuai budaya perusahaan tersebut.

Untuk mengubah budaya perusahaan diperlukan usaha keras untuk melakukan perubahan organisasi yang dilakukan secara bertahap, terlebih untuk mendukung perubahan pola kerja dengan sistem komputerisasi. Perubahan organisasi tersebut biasanya dimulai dengan memberikan contoh atau teladan dari level top management dan manajerial, yang secara bertahap akan diikuti level berikutnya. Tantangan terbesar dalam melakukan implementasi sistem ERP adalah bukan dari pengaruh perangkat teknologi informasi dan sarana infrastruktur teknologi modern. Tantangan yang terbesar adalah faktor sumber daya manusia. Mengubah pola pikir (mindset) orang untuk melakukan perubahan pola kerja dari cara kerja tradisional (manual) menjadi system komputerisasi (automate system) dengan penggunaan sistem ERP merupakan tantangan yang berisiko dan memerlukan waktu yang relatif lama.

Perubahan pola kerja tersebut dipengaruhi oleh budaya perusahaan. Untuk mengubah budaya perusahaan, maka diperlukan contoh teladan (role model) dari pimpinan. Manajemen perusahaan dituntut untuk memiliki tekad dan komitmen kuat untuk mendukung implementasi sistem ERP. Perubahan budaya perusahaan identik dengan pengelolaan sumber daya. Tantangan adalah bagaimana mengelola sumber daya agar dapat memiliki pola pikir yang mau berubah untuk berkomitmen meningkatkan produktivitas kerja, memiliki kompetensi, berkualitas, meningkatkan cara kerja menjadi lebih efisien dan efektif yang dapat memberikan nilai tambah bagi perusahaan, yang akhirnya sumber daya manusia tersebut menjadi ahli dibidangnya.

Pengguna yang telah terbiasa mengerjakan pekerjaan dengan waktu yang relatif lama melalui cara kerja sistem yang tidak terintegrasi, tentunya kebiasaan ini sudah menjadi suatu karakter atau budaya perusahaan. Perubahan pola pikir tidak bisa dilakukan secara instan, tetapi memerlukan proses 
yang terus menerus dengan waktu yang relatif cukup lama. Untuk mengubah cara kerja dan pola pikir tersebut, maka tim implementasi memerlukan upaya dari level top manajemen sebagai contoh model, dengan pembentukan karakter yang baik dan pendekatan secara pribadi (personal approach), terlebih bagi pengguna yang sudah relatif lama bekerja menggunakan system yang tidak terintegrasi. Hal ini untuk mengurangi tingkat perlawanan (resistance) terhadap penggunaan aplikasi program yang terintegrasi.

Tujuan pembentukan karakter ini adalah sebagai upaya meminimalisasi tingkat perlawanan pengguna terhadap penerapan sistem baru. Pada prinsipnya, pengguna akan merasa tidak bersemangat dalam menjalankan suatu sistem baru yang belum dikenal, karena pengguna harus mengikuti pelatihan dengan waktu yang intensif untuk menjalankan suatu aplikasi program yang terintegrasi. Disamping itu, perlu melakukan sosialisasi secara intensif dan memberikan pemahaman bahwa Implementasi suatu sistem ERP merupakan salah satu sarana untuk mempermudah tiap pengguna dalam mencapai tujuan perusahaan, sampai pengguna dapat memiliki system informasi yang terintegrasi ini.

Perubahan pola kerja juga sangat dipengaruhi oleh faktor-faktor berikut: (1) Sistem Informasi (Information System); sistem Informasi yang didukung dengan penggunaan Teknologi Informasi merupakan syarat mutlak untuk mencapai tingkat efektif dan efisiensi dalam melakukan operasional suatu Perusahaan. Keberadaaan suatu system informasi yang terintegrasi, yang biasanya dikenal dengan Enterprise Resouce Planning (ERP) atau Enterprise System (ES) sudah merupakan syarat standar minimal yang harus dimiliki suatu perusahaan. Permasalahannya adalah belum optimal pemanfaatan perangkat teknologi informasi oleh pengguna dalam menjalankan suatu sistem informasi yang terintegrasi. Faktor investasi sudah tidak menjadi kendala, karena nilai investasi pengadaan software system informasi tersebut dapat disesuaikan dengan kemampuan perusahaan. (2) Pengetahuan (Knowledge); untuk memastikan pelaksanaan implementasi suatu sistem informasi berjalan baik, maka diperlukan penguasaan pengetahuan pengguna (transfer knowledge) terhadap pelaksanaan cara kerja dari suatu aplikasi sistem informasi yang terintegrasi tersebut. Untuk itu, sangatlah dibutuhkan pelatihan (training). Tujuan pelatihan agar pengguna terlibat aktif dan membuat pengguna memahami secara mendetail pola kerja menjalankan aplikasi sistem baru yang terintegrasi tersebut. (3) Karakter (Character/ Attitute); karakter adalah mutlak dibutuhkan dari setiap pengguna yang akan mengikuti proses pelatihan dalam tahap trial simulasi dan implementasi suatu sistem informasi yang terintegrasi. Karakter ini akan mempengaruhi pola pikir pengguna terhadap keberadaan sistem baru tersebut. Perubahan pola pikir pengguna tersebut, dituntut untuk memiliki komitmen kuat dan persepsi yang sama dengan tim implementasi project terhadap tujuan mengembangkan implementasi sistem informasi yang terintegrasi. Dengan demikian pengembangan implementasi system informasi dapat sinkronisasi dengan strategi bisnis perusahaan jangka panjang. (4) Tanggungjawab (responsibility); Sikap tanggung jawab dari pengguna merupakan hal penting dan menentukan keberhasilan implementasi sistem informasi yang terintegrasi. Di mana pengguna akan memberikan respon yang cepat atas kendala permasalahan yang dihadapi dan terlibat aktif terhadap tim support implementasi system, dan bukan sebaliknya bersikap pasif. (5) Kepercayaan (respect); sikap memberikan kepercayaan (respect) dari para pengguna terhadap sistem yang terintegrasi yang akan dikembangkan, merupakan suatu sikap yang memberikan pemikiran positif, di mana pengguna dapat berpikir bahwa dengan keberhasilan implementasi System informasi yang terintegrasi, tentunya dapat meningkatkan efisiensi pekerjaan, dan pengguna akan lebih mengarahkan kepada pengendalian (control) dan evaluasi atas laporan atau informasi yang dihasilkan suatu Sistem informasi seperti ERP. Apabila pengguna tidak memberikan kepercayaan atas aplikasi program, maka tidak heran yang terjadi bahwa pengguna tidak menjalankan atau menginput transaksi dalam aplikasi program, tetapi masih menggunakan sistem lama. Terlebih halnya dalam aplikasi program, di mana jika urutan pekerjaan tidak dilakukan, maka proses pekerjaan selanjutnya tidak bisa dilakukan. Sering terjadi bahwa tidak adanya pendamping dari pengguna yang mengerjakan penginputan data pada aplikasi program, dan jika terjadi pengguna tersebut tidak masuk bekerja, maka penginputan data pada proses selanjutnya tidak dilakukan, dengan memberikan berbagai alasan tertentu. Hal ini yang perlu 
diperhatikan dengan serius agar transaksi penginputan data pada aplikasi program tidak mengalami hambatan yang disebabkan ketidakpercayaan dari pengguna.

\section{Infrastruktur Sistem ERP}

Untuk menjamin agar sistem ERP yang dibangun berjalan baik, maka perlu diperhatikan komponen-komponen dari infrastruktur sistem ERP, yaitu sebagai berikut: (a) People; orang-orang yang terlibat dalam implementasi sistem ERP adalah orang-orang yang memiliki kompetensi di bidangnya, memiliki komitmen waktu (time commitment), mendukung terhadap jalannya sistem ERP (management support), memiliki rasa memiliki (sense belonging) terhadap keberhasilan implementasi sistem ERP, mau terlibat secara aktif (involment actively), memiliki semangat dan minimum tingkat perlawanan (spirit and minimum resistance), dan dapat bertindak sebagai agen perubahan (agent of change). Menurut Monk, (2009), bahwa tantangan dalam implementasi sistem ERP adalah bukanlah dalam mengelola teknologi, tetapi dalam mengelola orang (managing people). Sistem ERP akan mengubah cara kerja orang untuk bekerja secara efisien dan efektif. Untuk itu, perlu ada perubahan cara kerja atau perubahan budaya perusahaan. Untuk itu, perlu dukungan dan komitmen dari level managerial dalam membangun suatu sistem ERP. (b) Technology; penerapan sistem ERP memerlukan tingkat investasi yang relatif tinggi, terutama dalam pengadaan perangkat keras, perangkat lunak, dan telekomunikasi. (c) Process; penerapan sistem ERP, secara otomatis akan mempengaruhi proses bisnis. Untuk itu, perlu diperhatikan dengan penggunaan aplikasi program, akan terjadi perubahan budaya perusahaan.

\section{Strategi Membangun Sistem ERP}

Keberhasilan membangun sistem ERP, tergantung strategi implementasi yang diterapkan. Beberapa strategi yang dapat diterapkan dalam mendukung keberhasilan membangun Sistem ERP adalah sebagai berikut: (1) Pengguna Fokus dan Teknologi Fokus; pengguna berusaha agar sistem ERP dapat mendukung proses yang saat ini sedang berlangsung, sehingga sistem ERP ditentukan untuk fleksibel. Untuk itu implementasi sistem ERP harus berfokus pada kebutuhan pengguna (user requirement). Setelah fokus pada pengguna dapat terpenuhi, maka fokus pada teknologi dapat dipertimbangkan. (2) Alokasi Sumber Daya Manusia; inovasi bisnis yang efektif memerlukan dukungan pimpinan manajemen. Tim yang terlibat pada implementasi sistem ERP, harus orang yang memiliki reputasi dan integritas pada bidangnya dan memiliki akses atau pengaruh yang kuat di perusahaan, sehingga dapat menjaga agar proyek implementasi sistem ERP tetap berjalan pada jalurnya. Tim harus melibatkan pengguna dan spesialist Teknologi Informasi, yaitu orang yang memahami proses bisnis perusahaan dengan baik. (3) Dukungan Konsultan; idealnya perusahaan memiliki kendali utama atas dukungan konsultan luar dalam melakukan implementasi sistem ERP. Hal ini bertujuan agar terjadi transfer pengetahuan dan pengalaman dari pihak konsultan dalam melakukan implementasi sistem ERP. Sebelum menunjuk pihak konsultan luar untuk implementasi sistem ERP, sebaiknya pihak internal perusahaan telah menentukan sasaran-sasaran perbaikan (improved), menentukan tujuan (goalsetting), dan kalkulasi keuntungan menggunakan konsultan luar tersebut. Dengan demikian, pihak konsultan dapat memberikan pelatihan kepada pengguna, menyusun standar prosedur, dan hal lain yang diperlukan, sehingga terjadi transfer pengetahuan dan pengalaman seperti yang diinginkan pihak perusahaan. (4) Pelatihan merupakan aspek penting pada implementasi sistem ERP. Beberapa faktor penyebab kegagalan implementasi sistem ERP adalah akibat buruknya materi pelatihan yang diberikan kepada pengguna. Kesuksesan implementasi sistem ERP, dapat dipengaruhi oleh tingkat penyerapan dan penerimaan manajemen dan pengguna (karyawan) terhadap pelatihan. 


\section{Perubahan yang Terjadi dengan Peranan Sistem ERP dan Perubahan Pola Kerja}

Sebelum penerapan sistem ERP dan pola kerja masih manual, perusahaan mengalami penurunan omset perusahaan di tahun 2012. Peningkatan omset perusahaan terjadi di tahun $2013 \mathrm{~s} / \mathrm{d}$ Q1 2014 dengan penerapan sistem ERP dan perubahan pola kerja. Pengguna dituntut menggunakan sistem baru yang belum dikenal dan belum dipahami, sementara pengguna telah terbiasa dengan waktu yang relatif lama dalam mengerjakan pekerjaan dengan cara kerja sistem yang belum terintegrasi. Kebiasaan ini tentu sudah menjadi suatu karakter atau budaya perusahaan. Contohnya, pengguna telah terbiasa menjalankan aktivitas perusahaan menggunakan telepon dan hardcopy. Pengguna telah merasa nyaman dengan lingkungan dan pola kerja sekarang, sehingga merasa enggan untuk mengikuti pelatihan-pelatihan dengan pola kerja yang belum dikenal, yang biasanya dikenal dengan zona ketidaknyamanan (sistem baru). Terlebih pada penguna dengan usia yang relatif senior, maka pengguna ini enggan untuk belajar pada teknologi informasi canggih dan merasa rendah diri untuk mengikuti pelatihan yang sebagian besar adalah orang-orang muda yang energik dan dinamis. Setelah diberikan pelatihan yang terus menerus dan diubah budaya kerja maka dampak pelatihan dapat dirasakan oleh pengguna dan dibuktikan dengan kinerja perusahaan yang terus bertumbuh dari tahun ke tahun.

\section{SIMPULAN}

Dari pembahasan yang telah dilakukan, dapat disimpulkan bahwa sistem ERP dan dunia bisnis tidak dapat dipisahkan, karena sistem ERP akan mendukung dan membantu kegiatan operasional dalam rangka meningkatkan efisiensi dan efektif, yang akhirnya memberikan keuntungan bagi perusahaan. Sistem ERP memiliki peran yang signifikan terhadap kinerja Perusahaan. Untuk mencapai hal tersebut, maka diperlukan perubahaan pola kerja. Perubahaan pola kerja akan menentukan keberhasilan dalam penerapan sistem ERP yang dibangun berhasil baik. Untuk itu, perlu adanya tingkat keselarasan antara strategis bisnis dengan sistem ERP, dengan memperhatikan hal-hal berikut: ketersediaan komponen infrastruktur sistem ERP, manajemen perubahan yang baik, komitmen mulai dari level manajemen sampai ke pengguna, perubahan pola kerja perusahaan.

\section{DAFTAR PUSTAKA}

Monk, E. F., Wagner, B. J. (2009). Concepts in Enterprise Resource Planning. $3^{\text {rd }}$ Edition. Massachusetts: WesternMichiganUniversity, Course Technology.

O’Leary, D. E. (2009). Enterprise Resources Planning Systems: System, Life Cycle, Electronic Commerce, and Risk. UK: CambridgeUniversity Press.Cambridge.

Turban, E., Aronson, J.E., Liang, T. P. (2005). Decision Support Sistem and Intelligent Sistems. 6th Edition. New Jersey: Prentice Hall International. 